\title{
Agrobiodiversity as Necessary Standard for the Design and Management of Sustainable Farming Systems
}

\author{
DOI: $10.18196 /$ pt.v10i1.14105
}

\author{
Bruno Borsari ${ }^{1,2}$ \\ ${ }^{1}$ Biology Department, Winona State University, Winona, MN 55987, USA \\ ${ }^{2}$ Minnesota State College Southeast, Winona, MN 55987, USA \\ *Corresponding author, email: bborsari@winona.edu
}

\begin{abstract}
Agriculture constitutes the major planetary force, which over the course of the past century has been changing forever the connotations of terrestrial ecosystems, due to its dependence on resources and impacts (e.g.: global climate change, biodiversity loss, pollution, and eutrophication of fresh and coastal waters). The purpose of this work aimed at demonstrating the compelling need to design and manage modern farms in a way that these may conserve, and even foster biodiversity because its restoration offers resilience, longevity, and productivity to $21^{\text {st }}$ century farms. Therefore, special emphasis in this work was given to the management of agricultural soils and agroforestry. These approaches enhance biological diversity, while strengthening the health of plants, animals, and human communities thus, contributing to the health of planet Earth. Agroecology is the science, practice and social movement that effectively, can assist with a conversion of farming systems toward sustainability and a restoration of agrobiodiversity.

Keywords: Climate change, Biodiversity loss, Pollution, Sustainability
\end{abstract}

\begin{abstract}
ABSTRAK
Pertanian merupakan kekuatan utama planet, yang selama beberapa abad telah mengubah makna ekosistem terrestrial, karena pertanian memiliki ketergantungan pada sumber daya dan menimbulkan dampak pada sumberdaya itu sendiri (misalnya: perubahan iklim global, hilangnya keanekaragaman hayati, polusi, dan eutrofikasi air tawar dan pesisir). Tujuan dari studi ini ditujukan untuk menunjukkan kebutuhan yang penting untuk merancang dan mengelola pertanian modern dengan cara yang dapat melestarikan dan mendorong keanekaragaman hayati, karena cara tersebut menawarkan ketahanan, keberlanjutan pertanian jangka panjang, dan produktivitas untuk pertanian abad ke-21. Sehingga, penekanan khusus pada studi ini diberikan pada pengelolaan tanah pertanian dan agroforestri. Pendekatan ini akan meningkatkan keanekaragaman hayatinya yang dapat memperkuat kesehatan tanaman, hewan, dan komunitas manusia sehingga berkontribusi pada kesehatan Bumi. Agroekologi adalah ilmu, praktik dan gerakan sosial yang secara efektif dapat membantu konversi sistem pertanian menuju keberlanjutan dan pemulihan agrobiodiversitas.
\end{abstract}

Kata kunci: Perubahan iklim, Keanekaragaman hayati, Polusi, Keberlanjutan

\section{INTRODUCTION}

For the last 10.000 years, agriculture has been playing a pivotal role in securing humans' food needs and for contributing to people's health and well-being. The latter is substantiated by a successful establishment of civilizations in various regions of the world where agriculture first occurred. An exponential growth of the human population during the last 200 years of human history could be considered another remarkable success of agriculture, that was amplified by the technological breakthroughs of the industrial revolution, like the

combustion engine and more implements, that were successful in boosting crop yields. Nevertheless, since the onset of agriculture an on-going conversion of land to farmland has been occurring at an increasing scale, through millennia (Mazoyer $M \&$ Roudart L, 2006). At present, scientists have calculated that livestock and crops agriculture have been shifting the $39 \%$ of all suitable lands to food production (Foley et al., 2011), making agriculture and the technologies it uses such as: transgenic crops, agrichemicals, computer networks, automa- 
tion, and large farm implements, a geologic force whose scale of disruption has forever changed the attributes of terrestrial biomes (Rockström J \& Gaffney O, 2021).

The relevance of this work is about the urgent need of changing agriculture into a more sustainable paradigm of regenerative and restorative food production, making agroecology a suitable vehicle for transformation and for achieving sustainability in modern farming. An agroecological approach to agriculture appears to be applicable to all farms and beneficial to people and the environment. Thus, the focus of this paper was directed to:

- Demonstrate how a design and management of modern farms with agroecology can preserve and even augment biodiversity.

- Illustrate the interconnectedness between soil biodiversity and agrobiodiversity.

- Present agroecology as the science, practice and social movement that can assist with a conversion of farming systems toward sustainability.

Agriculture relies heavily on the abundance and diversity of species that are cultivated, including those already existing on site, and that can be measured on a farm (Duru et al., 2015; Nicholls CI \& Altieri MA, 2016). Biodiversity can be considered at various levels spanning from the genetic diversity within a population to the community level, where it expands to describe diversity among multiple populations (Primack RB, 2006). Every species has its specific function in every ecosystem, despite inevitable redundancy, which is necessary to support ecological resilience thus, making biodiversity a keystone service whose losses indicate clear signals that humanity's life support system is out of balance (Tallamy DW, 2009). Since the beginning of agriculture in Neolithic times, the biomass from terrestrial plant species has been reduced $50 \%$ of its estimated diversity (Erb et al., 2018). According to Díaz and team (2019), this loss equals a loss of more than $20 \%$ of the original biodiversity among plants, implying that $70 \%$ of the Earth's land surface, which includes also large, marginal areas not as suitable for agriculture, has been severely disturbed by human activities (IPBES $\&$ Willemen, 2018). Primary causes of biodiversity loss are reported (Table 1).

Therefore, there is an urgent need to remediate from the loss of biodiversity to avert grave consequences that may jeopardize quality of life as we know it and to prevent a collapse of food systems, and associated food supply chains. A roadmap to transform agriculture and veer food production toward sustainability has been proposed, with specific emphases that aim at:

- Enhancing the regenerative capabilities of farming where land managed in agricultural systems is converted to sequester carbon, instead of continuing to emit carbon (Rockström J \& Gaffney O, 2021; Borsari B, 2022).

- Reducing, or even better eliminating food spoilage and waste (IPBES \& Willemen, 2018).

- Embracing unilaterally the planetary diet as proposed by the EAT-Lancet Commission (Rockström J \& Gaffney O, 2021).

- Stabilizing the human population to a size that is compatible with the regenerative capabilities of Earth, to avoid exhausting resources and without reaching the population carrying capacity.

However, it remains uncertain whether agriculture around the world will follow these guidelines, or not. The mentioned urgency consists in avoiding further greenhouse gas emissions (GHGs) in the atmosphere that could worsen the climate change 
Table 1. Causes of Biodiversity Loss and its Consequences.

\begin{tabular}{ll}
\hline Biodiversity Loss & Effects/Outcomes \\
\hline Habitat destruction & $\begin{array}{l}\text { Agriculture* and Infrastructure (railroads, airports, urbanization, } \\
\text { industry, etc.) }\end{array}$ \\
Global Climate Change & $\begin{array}{l}\text { Habitat and food loss from temperature change. Disruption of } \\
\text { migration patterns }\end{array}$ \\
Pollution of air, land, and water & Fossil fuels, pesticides, sewage, solid waste. \\
Non-native species & Cats and rats on islands, water hyacinth and more. \\
Overexploitation & Species hunted for food, pet trade, medicine. Logging, mining, fishing, \\
& groundwater extraction. \\
\hline
\end{tabular}

${ }^{*}$ Agriculture is the keystone cause of habitat and biodiversity loss, climate change and pollution.

scenarios to the point beyond recovery and control. There is a need of mobilizing society across geographic boundaries, economies, and culture, in a unilateral effort to comply and achieve the 17 goals for sustainable development (SDGs) of agenda 2030, as proposed by the United Nations, six years ago.

THE BENEFITS OF AGROBIODIVERSITY IN AGROECOSYSTEMS

Agrobiodiversity provides a multitude of valuable benefits to farming systems, while extending the same to the surrounding landscape where food production is taking place (Duru et al., 2015; Nicholls CI \& Altieri MA, 2016; Borsari B, 2022). More specifically, high biodiversity on the farm means:

- Greater microhabitat differentiation (Zucconi F, 1996).

- Increased opportunities for coexistence among beneficial species (Borsari B, 2022).

- Making possible various kinds of beneficial population dynamics among herbivores and their predators (Nicholls CI \& Altieri MA, 2016; Lampkin N, 1999).

- Better resource use in the agroecosystem (e.g.: three sisters intercropping and their use of soil nutrients) (Gliessman S, 2015).

- Reducing risks of crop failure for the farmer (Borsari B, 2022).

- Contributing to the conservation of diversity in nearby natural areas ((Nicholls CI \& Altieri MA, 2016; Borsari et al., 2016).
Moreover, diversity of the soil food web benefits nutrients recycling, regulation of local hydrological processes and detoxification of noxious chemicals, making these processes and services renew soil fertility and health. These advantages have been forgotten due to an excessive reliance of agriculture on input substitution from off farms, that for the last seventy years have been praised as the necessary means and technologies needed to achieve success in food production (Gliessman S, 2015). However, this western approach has marginalize indigenous knowledge and wisdom of farming, while spurring a significant loss of landrace seeds that were deemed irrelevant, or unprofitable by emerging agribusiness corporations (Borsari B, 2022). A restoration of indigenous knowledge in agriculture is much needed instead to conserve native germplasm for future generations and to assist also with a diversification of the human diet.

\section{Agronomic Approaches to Foster Agrobiodiversity in the Soil}

The most intuitive example for increasing agrobiodiversity consists in intercropping more than one plant or grazing more than one animal species in the same field. More strategies could include:

- Cover cropping

- Crop Rotations

- Intercropping (Mexican milpa as classic example with three sisters' cultivation method)

- Fallow cropping (resting field)

- Reduced, or minimum tillage 
- High organic matter (OM) inputs (compost)

- Reducing/eliminating the use of agrichemicals

- Employing trees (Agroforestry)

The challenge consists in designing agroecosystems that rely on resources already available on the farm and that blend in with the surrounding, natural landscape, while being aware of the ecological benefits that derive from it and thus, remaining committed to conserve and maintain its integrity (Nicholls CI \& Altieri MA, 2016; Gliessman S, 2015; Lampkin N, 1999).

\section{AGROBIODIVERSITY AND AGROFORESTRY CONTRIB- UTE TO SOIL HEALTH}

The abundance of life within the soil and the diversity of the soil community plays a very important role in achieving a healthy soil, which will enhance the health of all crops and livestock that depend on it (Borsari et al., 2016). The processes occurring in a soil that is biologically rich, contribute most effectively to an enhancement of carbon sequestration and humification, as it occurs during the composting process (Nair PKR, 2002).

Therefore, various types of biomass and crop residues (e.g.: foliage, stubble, chaff, brush) and/or animals' manure that left, or disked into the topsoil, will be transformed in humus (stable organic matter), are excellent resources for enhancing soil quality (Nair PKR, 2002). Consequently, when conducting an evaluation of soils, indicators like microbial activity and the amount of stable organic matter (OM), derived from biomass humification will be keystone markers of soil quality and health. Humus is a very stable form of carbon and thus, it is a pivotal component of soil fertility (Borsari B, 2020), making an understanding of the carbon cycle occurring within the soil and the biological processing of raw organic matter important knowledge that when applied to agriculture, assists farmers to restore soil fertility (Zucconi F, 1996). The fresh/raw OM goes through two distinctive humification process trajectories that can be fast, or slow depending on biotic factors (e.g.: richness and diversity of soil biota), and abiotic conditions such as: aerobiosis, air temperature, humidity, and carbon/nitrogen ratio of the biomass to be processed. Initially, both decomposition paths will yield organic compounds that are chemically unstable and toxic, removing water and carbon dioxide from the biomass, through exothermic reactions (Figure 1).

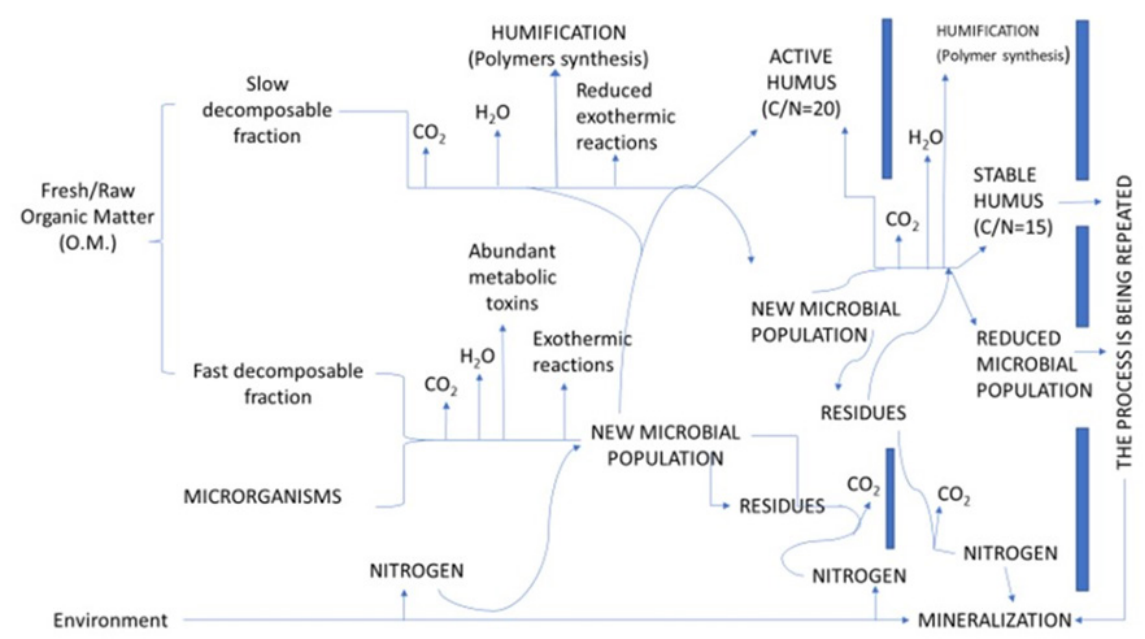

Figure 1. Cycle of decomposition and humification of fresh/raw organic matter (Borsari, 2020) 
At this stage of the process is not advisable to apply OM that is only partially humified, to seedlings, or germinating seeds, without incurring in toxicity induced damages to these. Only at the end of humification, when the mass will be reduced significantly in volume, the same becomes dark in color and earthy smelling, indicating the presence of actinomycetes. Its carbon/nitrogen ratio will drop to a more balanced ratio $(\mathrm{C} / \mathrm{N} \sim 15)$. At this stage, the humus rich compost will be chemically stable and ready to be used (Lampkin N, 1999). Also, the molecules yielded prior to the mineralization stage of the humification process (where mineralization refers to the decomposition/oxidation of macromolecules present in the OM, by which the nutrients in those compounds are released in soluble inorganic forms and become available to plants for uptake by their roots), stabilize the carbon molecules that have been converted in humus, which will accumulate in the topsoil (Nair PKR, 2002). This will make the soil retain mois- ture and plant nutrients, improving its resilience from disturbances like tillage, while enhancing its overall health.

Thus, a quantitative evaluation of soil health should include a variety of field measurements, in addition to standard soil nutrient analyses. These methodologies are available to farmers, enabling them to make the best decisions for planning and implementing practices of soil health enhancement and management that reduce the impacts of agricultural stressors (Moebius-Clune et al., 2017). However, it remains still difficult to find an agreement about adopting standardized methods when evaluating soil quality and health, despite the array of indicators available (Laishram et al., 2012). If the focus of a soil health assessment is adaptive to climate change, then key indicators should comprise soil structure, $\mathrm{OM}$, available carbon and nitrogen, microbial activity, including abundance and diversity of soil biota (Borsari et al., 2016; Nair PKR, 2002; Allen et al., 2011). Present knowledge

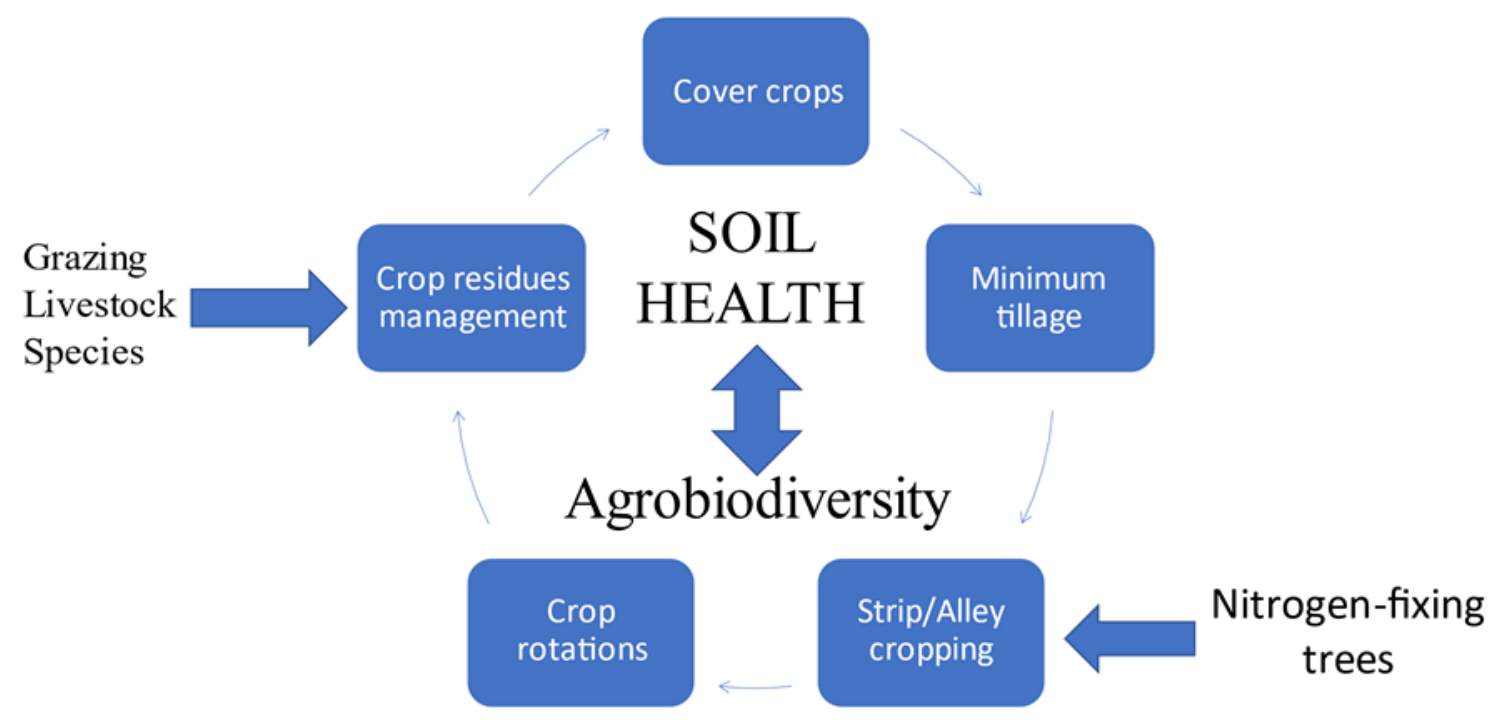

Figure 2. The nexus between soil health and agrobiodiversity relies on agronomic practices that prioritize an ecological management of the soil ecosystem (Borsari, 2022) 
about soil quality has improved in recent years, to clarify how soil health can be enhanced, or reestablished when it is affected by conventional farming practices. Yet, some barriers are still affecting a valid quantification of soil health by the fact that this topic is still new and by measurements that continue to be taken only in the topsoil (horizon A of the soil profile), ignoring deeper horizons (Sparling et al., 2004). Nonetheless, an integration of agronomic techniques, which includes also grazing animal species and nitrogen fixing trees will eventually, strengthen agrobiodiversity and soil health when these practices will become established permanently, in farm management (Figure 2).

\section{Agroforestry in Agroecosystems}

Agroforestry is an intentional integration of trees, crops and/or livestock in agroecosystems, where interactions are managed intensively. An employment of trees and other woody plants like shrubs can be a feasible approach to enhance agrobiodiversity and resilience in farms, while boosting a variety of additional products and services, that can increase the profitability of the farm enterprise (Gliessman S, 2015). Whether agroforestry is complemented by livestock grazing (e.g.: silvopasture), or the cultivation of agronomic plant species like in alley cropping, trees and other perennial plants are valuable to protect the farm and its crops, from soil erosion through windbreaks, or riparian buffer zones. Moreover, forest plots can be considered agroforestry systems when these are farmed with economic crops like mushrooms, medicinal plants, or woody plant species that can be used for construction and/or as a renewable energy source, for cooking and heating purposes.

Although agroforestry systems are ubiquitous their prevalence is in the agrarian landscapes of tropical and sub-tropical regions of the world. Their design and size may change according to topography, climate, soil characteristics, hydrology, and economic purpose from which market demand for its products and services depend. For example, in sub-tropical highland regions of India, with altitudes $>1000 \mathrm{~m}$ above sea level, agroforestry has become a key approach to farming, and for protecting soil from erosion. Therefore, intercropping bamboo (Bambusa spp.) and rice (Oryza sativa L.), with an integration of aquaculture constitutes the design and practice of common agroforestry systems in these dry regions, where scarce rain precipitations and high daily temperatures, cause frequent droughts (Raj et al., 2021). More specifically, agroforestry has been beneficial to farmers in the dry corridor of Rajasthan, to diversify farm products through an inclusion of Ghaf trees (Prosopis cineraria), together with cereals and pulses, thus, enhancing economic gains and agrobiodiversity (Dhanya et al., 2014). An integration of pigs who are raised often in bamboo shelters built on the edge of the rice fields, adds meat to the number of products (e.g.: fish, rice, bamboo) and services (e.g.: pig manure as feed for the fish and animal waste), including scales, and nitrogen-rich manure, that restores soil fertility in countries of southeast Asia. These multifunctional agroecosystems provide food security for local communities, while maintaining an optimal level of land use for agriculture (Tangjang S, 2016). In the dry arc (Arco seco) region of Panama instead, the Physic nut tree (Jatropha curcas L.) is employed in silvopasture, as a viable species to construct live fences for containing cattle and for producing biodiesel from the seed harvested from this tree (Espinosa-Tasón et al., 2016).

Also, home gardening can be considered common and productive agroforestry systems that are cultivated in many tropical and non-tropical regions of the world, including urban and periurban areas (Orsini et al., 2020). These and similar growing spaces have potential to improve farmers' 
income while securing food for their families and communities. Fruit and nut trees bear these products in the upper layer of their canopy, intermingled with vines (e.g.: spice crops) growing in the middle layer, whereas the understory is designed to grow cash crops, or medicinal plants, even on small spaces. Green hedges employing an assortment of trees and shrubs mark the boundaries among adjacent home gardens, making this form of intentional landscape, an ancient landscaping practice (Raj et al., 2021). Agroforestry gardens replenish the built environment with abundant edible products enhancing air quality, water retention and more ecological services, while beautifying the urbanscape. Also, green, live hedges function as fences/windbreaks, improving soil fertility by adding some of their biomass to the soil nearby (Gliessman S, 2015). Instead, an integration of trees with grasses, pulses, and grazing livestock, or silvopasture, consists in a distinctive form of agroforestry where a well-maintained plant community is supportive of the nutrition and health of the animals. Iconic tree species used in tropical and sub-tropical silvopasture include neem (Azadirachta indica), mango (Mangifera indica), acacia (Acacia nilotica), or Leucaena (Leucaena leucocephala Lam.), whereas in temperate regions oaks may be common (Oak spp.), including the cork oak (Quercus suber) of the "dehesa" in Spain, or black locust (Robinia pseudoacacia), willow (Salix spp.), poplar (Populus spp.). Silvopasture supplies distinctive ecosystem services that maintain the ecological balance of the whole system. For example, in the tropics acacia species found sparsely on farmland is a good source of timber, fuelwood and gum (Raj et al., 2021), as well as cork oak in the Iberic peninsula of western Europe that provides bark to make corks for the wine industry, in addition to acorns that consumed by pigs yield the famous 'Serrano' and/or 'Iberico' ham. A robust body of scientific literature verifies further the multifaceted benefits of agroforestry (economic, social, agronomic, environmental, etc.), and its applications around the world, in support of an agroecological design for spurring a sustainable agriculture.

\section{CONCLUSION AND FINAL REFLECTIONS}

Agriculture continues to remain the culprit and chief villain of all economic activities, emitting in the atmosphere the largest amount of carbon gases that are implicated in climate change (Crippa et al., 2021). It consumes the $70 \%$ of all freshwater use and its energy needs derive mostly, from nonrenewable sources $(-40 \%)$, in addition to the one coming from the sun. Massive conversions of land use into crop land and/or pasture are the symptoms of a dysfunctional agriculture that leads the way also in polluting freshwater with residues of pesticides, chemical fertilizers, hormones, antibiotics, and soil from erosion. This nefarious trend in agriculture is expected to grow further within the next three decades, due to a steady rate of population growth that although modest ( $\sim 1 \%)$, adds about 75 million people, to our crowded planet, every year (Springmann et al., 2018). Many agricultural experts continue supporting an intensification of food production, claiming biotechnologies, precision farming, automation and climate smart agriculture, the needed approaches, and tools, that will allow modern society to overcome this challenge and feed 10 billion people by 2050 . However, this extractive emphasis of the present agro-industrial model of food production is unsustainable and continues to operate as a major problem and challenge, to climate mitigation and sustainable development.

This is implying that modern agriculture and food supply chains are in a collision course with nature and this hazardous trajectory demands immediate attention and remediation actions. Agro- 
ecology provides feasible alternatives for agriculture small, dispossessed family farmers (Held L, 2021). to avert the calamitous, predicted consequences of For these reasons, agroecologists advise agroecolan unleashed Anthropocene yet, it involves much ogy groups and farmers' organizations to abstain more than preserving, or expanding traditional from partnering with private companies, or food agriculture, while extending food production to corporations (Rosset PM \& Altieri MA, 2017). This urban areas (Altieri MA \& Nicholls CI, 2020). warning should prevent a co-optation of their work A transformation of modern agriculture toward and values by the capitalistic interests of agribusisustainability is more likely to occur by re-estab- ness, as this model of agriculture remains pervasive lishing more robust links between farmers and across the agroindustry. Another challenge posed consumers because this relationship strengthens by industrial agriculture consists in its persuasive local economies and cultures that are foundation indoctrination of society with illusive narratives to forces of any food system (Gliessman S, 2015). A make believe that industrial agriculture is the only focus on education in food systems sustainability way of ensuring cheap, high-quality food to all, in should encompass entirely, the food production, great abundance. Unfortunately, this paternalistic distribution aspects, that in agroecology are inclu- rhetoric remains supported by many researchers, sive of the economic and socio-cultural aspects of who are employed in the colleges of agriculture of this primary human production sector (Onwueme land-grant universities, and who continue to receive et al., 2008; Borsari B, 2011). This more holistic generous funding from agribusiness corporations vision plan should invest not solely in research but for answering questions that may bring high lucraalso in education, while striving to reduce poverty, tive gains to the industry through patents an adinequalities, violence, and political antagonisms vanced technologies yet, these remain of marginal that too often escalate to tragic armed conflicts access, or utility to family farmers (Berry W, 1977). (within and among countries), destroying the liveli- Dietary changes veering towards eating habits hoods of millions and amplifying mass migrations that rely mostly on plant products like fruits, roots and misery. Access to food and land are sacrosanct and vegetables, coupled by advances in knowledge rights, which should be honoured, not only to pre- about agriculture and more emphasis on reducing serve the germplasm of plant and animal species food waste, are ideal strategies that can reduce that are pillar food foundations for humanity, but GHGs from the food system and mitigate successalso (and above all), to ensure dignity and respect fully, the global climate (Springmann et al., 2018). for every human being. However, tangible risks and uncertainty that agri-

Although agroecology is on an ascending curve culture in conjunction with other human activities of acceptance as a science, a practice and as a so- compromise planet Earth's homeostasis persist as a cial movement, its establishment is not free from disturbing reality. Nonetheless, a safe corridor of appropriations by industrial agriculture that has operation is achievable if human activities will be started to greenwash its image through the use of soon constrained within the limits of the planetary persuasive terminology, like climate-smart and/or boundaries (Rockström et al., 2021). To make this precision farming, intended to maintain the agri- possible, a four-pronged plan for transforming the business status quo in agriculture, that handled by food system, which was proposed by IPES-Food \& few, gigantic corporations continues to cause mis- ETC Group in 2021 must be enacted without delay ery and displacement from the land of millions of (Rockström J \& Gaffney O, 2021). This scheme 
offers a route that could shift trillions of US dollars from agribusiness to food sovereignty, agroecology, and similar programs thus, reducing $75 \%$ of GHG emissions generated by food systems, with immediate, benign effects on biodiversity, its preservation, and a slow restoration toward normality of biogeochemical cycles. An effective move in this direction demands for an urgent reallocation of agricultural subsidies from agribusiness corporations to family farmers and peasant cooperatives, or growers' associations who are committed to good stewardship as established by agroecological practices and with standards that are based on carbon sequestration in soils and biodiversity conservation, rather than overproduction (Borsari B \& Kunnas J, 2020) and corporative profits (Rosset PM \& Altieri MA, 2017). At this critical moment, it is imperative for society to transform itself, beginning with systemic changes to the food system. Shifts undergone by large segments of humanity during the Covid-19 pandemic in 2020, have demonstrated unimaginable resilience by farming systems where agroecology is applied and embraced as established practice in agriculture (Altieri MA \& Nicholls CI, 2020). These experiences remain as vivid memories of creativity and solidarity, defining at the end, the benign capabilities and resilience of humanity, while reiterating the potentials of agroecology to lead agriculture and food systems toward a restoration of agrobiodiversity and a unilateral pursuit of sustainability.

\section{REFERENCES}

Allen DE, Bhupinder PS, \& Ram CD. (2011). Soil Health Indicators Under Climate Change: A Review of Current Knowledge Soil Health and Climate Change eds BP Singh et al. Springer-Verlag Berlin Heidelberg, 24-45.

Altieri MA, \& Nicholls Cl. (2020). Agroecology: challenges and opportunities for farming in the Anthropocene. Int J Agric Nat Res, 47(3), 204-215.

Berry W. (1977). The Unsettling of America. Culture and Agriculture. Sierra Club Books.

Borsari B. (2011). Agroecology to the rescue of food security and germplasm conservation in a global market economy. Int $\mathrm{Ag}$ Res Gov \& Ecol., 9(1/2), 1-14.

Borsari, B. (2020). Soil Quality and Regenerative, Sustainable Farming Systems. In: A. M. and B. L. and Ö. P. G. and W. T. Leal Filho Walter and Azul (Ed.), Zero Hunger (pp. 823-832). Springer International Publishing. https://doi.org/10.1007/978-3-31995675-6 72

Borsari, B. (2022). From Agroecology to Food Systems Sustainability: An Evolutionary Path Shifting Toward Sustainable Agriculture and Development. (pp. 1-18). https://doi. org/10.1007/978-3-030-68074-9 8-1

Borsari, B., \& Kunnas, J. (2020). Agriculture Production and Consumption. In: Leal Filho W., Azul A., Brandli L., Özuyar P., Wall T. (eds) Responsible Consumption and Production. Encyclopedia of the UN Sustainable Development Goals. Springer, Cham

Borsari, B., Mundahl, N., Vidrine, M., Borsari, B., Mundahl, N., \& Malcolm, V. (2016). 6. A Comparison of Soil Biodiversity in Restored Prairie Plots and Agricultural Fields at a Biomass Production Farm in Southeastern Minnesota Recommended Citation A Comparison of Soil Biodiversity in Restored Prairie Plots and Agricultural Fields at a Biomass Production Farm in Southeastern Minnesota" (Vol. 16). https://ir.library.illinoisstate. edu/napc/16

Crippa, M., Solazzo, E., Guizzardi, D., Monforti-Ferrario, F., Tubiello, F. N., \& Leip, A. (2021). Food systems are responsible for a third of global anthropogenic GHG emissions. Nature Food, 2(3), 198-209. https://doi.org/10.1038/s43016-021-00225-9

Dhanya, B., Sathish, B. N., Viswanath, S., \& Purushothaman, S. (2014). Ecosystem services of native trees: experiences from two traditional agroforestry systems in Karnataka, Southern India. International Journal of Biodiversity Science, Ecosystem Services \& Management, 10(2), 101-111. https://doi.org/10. 1080/21513732.2014.918057

Duru, M., Therond, O., Martin, G., Martin-Clouaire, R., Magne, M.-A. Justes, E., Journet, E.-P., Aubertot, J-N., Savary, S., Bergez, J.-E., \& Sarthou, J. P. (2015). How to implement biodiversity-based agriculture to enhance ecosystem services: a review. Agronomy for Sustainable Development, 35(4), 1259-1281. https://doi. org/10.1007/s13593-015-0306-1

Erb, K.-H., Kastner, T., Plutzar, C., Bais, A. L. S., Carvalhais, N., Fetzel, T., Gingrich, S., Haberl, H., Lauk, C., Niedertscheider, M., Pongratz, J., Thurner, M., \& Luyssaert, S. (2018). Unexpectedly large impact of forest management and grazing on global vegetation biomass. Nature, 553(7686), 73-76. https://doi.org/10.1038/ nature 25138

Espinosa-Tasón, J., Borsari-Maraldi, B., \& Mighell-Johnson, K. (2016). EL COQUILLO (Jatropha curcas L.) PARA LA PRODUCCIÓN DE BIODIESEL EN LA REGIÓN DEL ARCO SECO, PANAMÁ. Ciencia Agropecuaria, 0(25). http://www.revistacienciaagropecuaria, ac.pa/index.php/ciencia-agropecuaria/article/view/99

Foley, J. A., Ramankutty, N., Brauman, K. A., Cassidy, E. S., Gerber, J. S., Johnston, M., Mueller, N. D., O'Connell, C., Ray, D. K., West, P. C., Balzer, C., Bennett, E. M., Carpenter, S. R., Hill, J., Monfreda, C., Polasky, S., Rockström, J., Sheehan, J., Siebert, S., ... Zaks, D. P. M. (2011). Solutions for a cultivated planet. Nature, 478(7369), 337-342. https://doi.org/10.1038/nature10452

Gliessman S. (2015). Agroecology. The Ecology of Sustainable Food 
Systems (3rd ed.). CRC Press.

Held L. (2021). Is Agroecology Being Co-Opted by Big Ag? Https:// Civileats.Com/2021/04/20/ls-Agroecology-Being-Co-Optedby-Big-Ag/?Fbclid=IwAR1zgK5gNOnDHnnmNK ofNIWQUE]z7l3Wz2GuGXQPcm266agFllk10etZw.

IPBES, \& Willemen, L. (2018). Summary for policymakers of the assessment report on land degradation and restoration of the Intergovernmental Science-Policy Platform on Biodiversity and Ecosystem Services.

Laishram, J., Saxena, K., Maikhuri, R., \& Rao, K. (2012). Soil quality and soil health: A review. International Journal of Ecology and Environmental Sciences, 38.

Lampkin N. (1999). Organic Farming (6th ed.). Farming Press, UK.

Mazoyer M, \& Roudart L. (2006). A History of World Agriculture. From the Neolithic Age to the Current Crisis. Monthly Review Press.

Moebius-Clune, B. N., Moebius-Clune DJ, Gugino DK, Idowu OJ, Shindelbeck RR, Ristow AJ, van Es HM, Thies JE, Shayler HA, McBride MB, Kurtz KSM, Wolfe DW, \& Abawi GS. (2017). Comprehensive assessment of soil health: the Cornell framework manual (3rd ed.). Cornell University.

Nair, P. K. R. (2002). The Nature and Properties of Soils, 13th Edition. By N. C. Brady and R. R. Weil. Agroforestry Systems, 54(3), 249. https://doi.org/10.1023/A:1016012810895

Nicholls, C., \& Altieri, M. (2016). Agroecology: Principles for the Conversion and Redesign of Farming Systems. Journal of Ecosystem and Ecography, 01. https://doi.org/10.4172/21577625.55-010

Onwueme, l., Borsari, B., \& Filho, W. (2008). An analysis of some paradoxes in alternative agriculture and a vision of sustainability for future food systems. International Journal of Agricultural Resources, Governance and Ecology, 7, 199-210. https://doi. org/10.1504/IJARGE.2008.018325

Orsini, F., Pennisi, G., Michelon, N., Minelli, A., Bazzocchi, G., SanyéMengual, E., \& Gianquinto, G. (2020). Features and Functions of Multifunctional Urban Agriculture in the Global North: $A$ Review. Frontiers in Sustainable Food Systems, 4. https://doi. org/10.3389/fsufs.2020.562513

Primack RB. (2006). Essentials of Conservation Biology (4th ed.). MA: Sinauer Associates, Inc.

Raj, D., Mehta, C., \& Sadawarti, R. (2021). Agroforestry as a Strategy for Sustainable Soil Management. J Ecol \& Nat Resour, 5(1), 000228. https://doi.org/10.23880/jenr-16000228

Rockström J, \& Gaffney 0. (2021). Breaking Boundaries: The Science of Our Planet. Dorling Kindersley Limited DK, a Division of Penguin Random House LLC, 239.

Rockström, J., Gupta, J., Lenton, T. M., Qin, D., Lade, S. J., Abrams, J. F., Jacobson, L., Rocha, J. C., Zimm, C., Bai, X., Bala, G., Bringezu, S., Broadgate, W., Bunn, S. E., DeClerck, F., Ebi, K. L., Gong, P., Gordon, C., Kanie, N., ... Winkelmann, R. (2021). Identifying a Safe and Just Corridor for People and the Planet. Earth's Future, 9(4), e2020EF001866. https://doi.org/https://doi. org/10.1029/2020EF001866

Rosset PM, \& Altieri MA. (2017). Agroecology Science and Politics. Agrarian Change \& Peasant Studies. Fernwood Publishing.

Sparling, G., Schipper, L., Bettjeman, W., \& Hill, R. (2004). Soil Quality Monitoring in New Zealand: Practical Lessons from a 6-Year
Trial. Agriculture Ecosystems and Environment, 104, 523-534. https://doi.org/10.1016/j.agee.2004.01.021

Springmann, M., Clark, M., Mason-D'Croz, D., Wiebe, K., Bodirsky, B. L., Lassaletta, L., de Vries, W., Vermeulen, S. J., Herrero, M., Carlson, K. M., Jonell, M., Troell, M., DeClerck, F., Gordon, L. J., Zurayk, R., Scarborough, P., Rayner, M., Loken, B., Fanzo, J., ... Willett, W. (2018). Options for keeping the food system within environmental limits. Nature, 562(7728), 519-525. https://doi. org/10.1038/s41586-018-0594-0

allamy DW. (2009). Bringing Nature Home. How you can sustain Wildlife with native plants. Timber Press.

Tangjang, S. (2016). Integrated bamboo + pine homegardens: A unique agroforestry system in Ziro Valley of Arunachal Pradesh, India. International Journal of Environmental \& Agriculture Research (IJOEAR), 2.

Zucconi F. (1996). Declino del Suolo e Stanchezza del Terreno . Spazio Verde. 